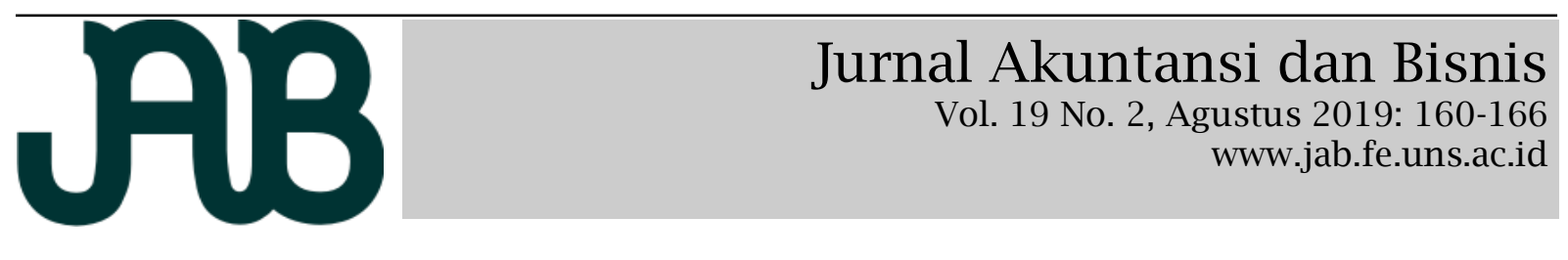

\title{
THE INFLUENCE OF FINANCIAL INCLUSION ON CREDIT RISKS IN COMMERCIAL BANKS IN INDONESIA
}

\author{
REZA GHASARMA ${ }^{1}$ \\ FIDA MUTHIA² (f.muthia@unsri.ac.id) \\ M.A. RASYID UMRIE ${ }^{3}$ \\ SULASTRI ${ }^{4}$ \\ BOBBY ARIANTO ${ }^{5}$
}

${ }^{1-4}$ Management Study Program, Faculty of Economics, Universitas Sriwijaya, Indonesia

${ }^{5}$ International Business, Monash University, Australia

\begin{abstract}
A B S T R A C T
This study aims to analyze the effect of financial inclusion on credit risk in commercial banks in Indonesia. The data used are secondary data obtained from the Financial Access Survey (FAS) of the IMF and Bank Focus from 2011-2016. A total of 34 banks were sampled in this study. From the results of panel data processing, it was found that financial inclusion has a positive effect on bank credit risk, where an in crease in the financial inclusion index annually causes an increase in bank credit risk. The results of this study provide insights to the government and banks to anticipate credit risk which can affect banking stability due to financial inclusion.

Keywords : financial inclusion, credit risks, panel data

Penelitian ini bertujuan untuk menganalisis pengaruh inklusi keuangan terhadap credit risks (risiko kredit) pada bank komersil di Indonesia. Data yang digunakan merupakan data sekunder yang didapatkan dari Financial Access Survey (FAS) IMF dan Bank Focus dari tahun 2011-2016. Sejumlah 34 bank menjadi sampel pada penelitian ini. Dari hasil pengolahan data panel, ditemukan bahwa inklusi keuangan memiliki pengaruh yang positif terhadap risiko kredit bank, dimana kenaikan indeks inklusi keuangan tiap tahunnya menyebabkan kenaikan pada risiko kredit bank. Hasil dari penelitian ini memberikan wawasan kepada pemerintah dan perbankan untuk melakukan antisipasi terhadap risiko kredit yang dapat berpengaruh kepada stabilitas perbankan akibat adanya inklusi keuangan.

Kata kunci : inklusi keuangan, risiko kredit, panel data
\end{abstract}

\section{INTRODUCTION}

In 2016 the government established the National Strategy for Inclusive Finance (SNKI) aimed at expanding banking access for the public, especially those that fall into the unbanked category (Parlina, 2016). SNKI program aims to improve public financial education due to the low demand of people in using financial institutions (Dienillah \& Anggraeni, 2016). Financial inclusion is an effort whereby all communities and businesses can access financial services (World Bank, 2017). Data from (Bank Indonesia, 2017) indicate that financial inclusion is addressed to deal with the impact of the 2008 crisis on the bottom-ofthe-pyramid group of low income groups, living in rural areas, lacking identity documents, disabilities and marginalized communities. The existence of financial inclusion is aimed at improving economic efficiency and financial stability, economic growth and reducing poverty (Bank Indonesia, 2017).

Many literatures explain the impact of financial inclusion. (Dienillah \& Anggraeni, 2016) explains that the increasing number of people who can access financial institutions can solve poverty, improve development and financial system. Similarly, (Dittus \& Klein, 2011) and (Manji, 2010) suggest that access to financial institutions is linked to economic growth, poverty reduction and income inequality. Further- 
more, several studies also discussed the impact of financial inclusion on the level of development. (Sarma \& Pais, 2011) find that there is a positive relationship between financial inclusion and the level of human development. This is in contrast to (Unnikrishnan \& Jagannathan, 2015) which states that the level of human development is due to life expectancy and education rather than financial inclusion so there is no relationship between human development level and financial inclusion in middle and high-income countries.

Banks as intermediary agents have a very important role in financial inclusion. Banks are expected to channel their access to the community, which is included in the unbankable category. This has a positive and negative impact on the bank. (Ahamed, 2016) reveals that a high level of financial inclusion increases the chances of banks to enlarge their consumer portfolio in remote areas and can also spread its loans. Furthermore, agency problems can be minimized as the asymmetric information loss between borrowers and lenders. However, (Ahamed, 2016) also states that, financial inclusion may pose problems to banks. Increasing the number of bank branches in remote areas will create supervisory problems for managers. Banks are also trying to attract consumers by following their preferences and trends that result in product nonconformity. These factors lead to high inefficiencies in the bank.

In addition, (Ahamed \& Mallick, 2017) explain that financial institutions also face some issues in providing financial access to communities. They argue that the lack of ownership of legal identity documents, collateral and collectability makes high operating costs as well as risks associated with services, oversight and debt administration. Research from (Musau, Muathe, \& Mwangi, 2018) in Kenya shows that increased financial inclusion led to high nonperforming loans that jeopardize bank stability by increasing the bank's credit risk. Therefore, by promoting financial inclusion the government indirectly makes commercial banks face credit risks, which in turn may affect the long-term stability of the banking system. However, research from
(Han \& Melecky, 2015) suggests that while governments face trade-offs in promoting financial inclusion and financial stability, there is a synergy between the two as the expansion of banking access to communities can help increase financial inclusion as well as overall financial stability.

There is very little research that discusses financial inclusion and credit risks in commercial banks. This is considered important because the bank has a very large share as an intermediary agent in increasing financial inclusion. On the other hand, if by increasing financial inclusion, the risks faced will be higher, then this can have a devastating impact on commercial banks. Thus, the government needs to create policies that can provide the best solutions for banks as well as programs to increase financial inclusion. Therefore, this study attempts to analyze the effect of financial inclusion on credit risks on commercial banks in Indonesia. This study tries to fill the gap on the effect of financial inclusion in bank performance in which, in this case, measured by credit risks.

This study provides several contributions; firstly, this study can show the relationship between financial inclusion and credit risks in commercial banks. Second, the results of this study may add to the literature on financial inclusion and its relationship to credit risks in commercial banks. Finally, the results of the study could be considered by the government as policy makers and banks as intermediary agents in the program of increasing financial inclusion.

The reminder of the paper proceeds as follows. In the next section, a literature review and hypothesis development are explained. Research methods, discusses the methodology used in this study, Analysis and Discussion section explains the findings of this study and Conclusion section concludes and highlights the limitation of this study.

\section{LITERATURE REVIEW AND HYPOTHESIS DEVELOPMENT}

Financial Inclusion

According to (Bank Indonesia, 2017) financial inclusion policy is a deepening finan- 
cial services focused on communities that fall within the bottom of the pyramid to use financial products and services. (World Bank, 2017) explains that financial inclusion is a condition whereby individuals and businesses have access to formal financial institutions on an ongoing basis to carry out their financial activities. Several studies have analyzed the inclusion of finances and their relation to some macroeconomics factors. (Sarma \& Pais, 2011) conducted a cross-country study to see the relationship between financial inclusion and the level of human development using Ordinary Least Square. They found that financial inclusion and the level of human development move simultaneously and income has a positive relationship with financial inclusion.

Different findings are presented by (Unnikrishnan \& Jagannathan, 2015) which reveal that there is no correlation between human development and financial inclusion in high and middle-income countries. Using Multiple Regression Analysis, this study focuses on analyzing the influence of financial inclusion index (FI) on the human development index (HDI), and the influence of Gross Domestic Product on FI-mediated HDI. The results of this study found that high HDI in high-income countries is due to higher life expectancy and education level. The financial inclusion measurement used in this study is the index of financial inclusion.

Furthermore, (Dienillah \& Anggraeni, 2016) examines the impact of financial inclusion on financial system stability in Indonesia. Financial inclusion in this study is measured by comparing total outstanding SME loan in commercial bank to total outstanding loan in a commercial bank. Using annual data from 2007-2011 and Pearson correlation and fixed effect model methods, it was found that there was a negative correlation between financial inclusion and financial stability.

Ahamed (2016) sees the effect of financial inclusion with bank efficiency. Financial inclusion is measured using the dimensions of accessibility (accessibility), availability and penetration, which are indicators of financial inclusion. The dimension is constructed using two-stage princi- pal component analysis (PCA) to obtain a financial inclusion index. The results of this study indicate that the high inclusion of finance can increase the level of cost and profit efficiency. The same proxy is also used by Sanjaya \& Nursechafia (2015) in calculating the index of financial inclusion. The results of the study reveal that financial inclusion is influenced by the dimension of accessibility.

\section{Credit Risks}

Credit risks are the risks associated if a borrower cannot repay the debt and the lender may lose the loan principal and interest from the loan (Investopedia, 2018). (Garr, 2013) examines the factors affecting credit risks in the banking industry in Ghana. Using time series data from 33 commercial banks in Ghana for 21 years (19902010), this study proves that credit risks in Ghana are significantly influenced by the efficiency of bank management, Gross Domestic Product Per Capita, government loans and financial sector developments. In calculating credit risks, (Garr, 2013) uses two proxies, namely, loan loss provision ratio with total assets and net interest income membrane with total assets.

A similar study in Ghana was also conducted by (Adu \& Adjare, 2010) who examined commercial banks in Ghana from 2007-2014. By using robust least squares regression analysis, this study found that there is a negative relationship between credit risks and profit. The proxy of credit risks used in this study is the ratio of total loans and advances to total assets. (Thiagarajan, 2016) using data panels of 5 private banks from 2006-2012 in Belize found that macroeconomic and bankspecific factors have an important role in determining credit risks in commercial banks. The proxy used in this study is lagged non-performing assets.

\section{The Relationship between Financial Inclu- sion and Credit Risks}

There is only a handful literature that examines the relationship of financial inclusion and credit risks. A study in Kenya by (Musau et al., 2018) found that bank availability, bank accessibility and bank usage as 
an indicator of financial inclusion have a significant effect on credit risks in commercial banks. The study used 43 commercial banks in Kenya from 2007-2015 as their sample. The study used multiple regression analysis to analyze the relationships of the variables tested. The study also shows that bank competitiveness also has a partial effect in mediating the relationship of financial inclusion and credit risks. Furthermore, (Ahamed \& Mallick, 2017) also revealed that credit risks in commercial banks may increase as banks seek to serve the undercover community at the bottom of the pyramid to use banking services. This is due to the lack of ownership of the legal identity documents, collateral and collectability of loans owned by such community groups.

Han \& Melecky (2015) argue that while there is a trade-off between promotion of financial inclusion and financial stability, there is a synergy utilized by the government for the expansion of banking access to society as well as overall financial stability. Banks as intermediary agents have an important role in financial inclusion in increasing the number of people belonging to the category of the bankable. However, if the bank provides services to people who are classified as bottom of the pyramid, there is a possibility that banks will experience an increase in credit risks. It is therefore important to know how financial inclusion relates to credit risks. Therefore the hypothesis of this study is as follows:

H1: There is an effect of financial inclusion on credit risk in commercial banks in Indonesia

\section{RESEARCH METHODS}

\section{Data}

In calculating the financial inclusion and credit risks, secondary data from annual reports, Bank Focus and Financial Access Survey (FAS) IMF are used. The population of this study is both conventional and sharia banks in Indonesia from 2011-2016 that is listed in Indonesia Stock Exchange, amounting up to 34 banks, with the number of observations of 159 . The selected years of observation is chosen to capture the after effect of the 2010 global crisis, we believe that it may have an effect on bank's credit risks.

\section{Data Analysis Method}

To see the effect of financial inclusion on credit risks, multiple regression is used with the following model:

$$
\text { Credit Risks } \mathrm{i}_{\mathrm{i}, \mathrm{t}}=\beta_{0}+\beta_{1} \text { FII }_{\mathrm{t}}+\text { Tahun }_{\mathrm{t}}+\varepsilon_{\mathrm{it}}
$$

CreditRisks $_{\mathrm{i}, \mathrm{t}}$ refers to the credit risks bank $\mathrm{i}$ at year t. FII is financial inclusion at year t. Tahunt is dummy variable for year and eit is an error term. We use year dummy as the control variable to control the year effects.

\section{Variables Measurement Credit Risks}

Credit risks represent a risk that occurs because the borrower cannot repay the debt and there is a possibility that the lender will not get the loan principal and loan interest from the borrower. In this study, the credit risks used are annual data in Rupiah that has been calculated and available in the Bank Focus database provided by Moody's Analytics.

\section{Financial Inclusion}

Financial inclusion is a condition where all adult individuals and businesses have access to financial products and services (transactions, payments, savings, credit and insurance) sustainably (World Bank, 2017). Some studies use the Financial Inclusion Index in measuring financial inclusion (Sanjaya \& Nursechafia, 2015; Unnikrishnan \& Jagannathan, 2015). Table 1 show the results of financial inclusion index calculation from 2011 to 2016. It can be seen that there was an increase in the financial inclu-

Table 1.

Financial Inclusion Index

\begin{tabular}{cc}
\hline Year & FII \\
\hline 2011 & 0.191 \\
2012 & 0.201 \\
2013 & 0.243 \\
2014 & 0.272 \\
2015 & 0.290 \\
2016 & 0.326 \\
\hline Notes: FI is a financial inclusion index
\end{tabular}

Notes: FII is a financial inclusion index calculated using the ratio of outstanding loans in small and medium enterprises to total outstanding loans in banks. 
sion index in the observation period where the highest index value occurred in 2016 amounted to 0.326. This increase can be indicated as the cause of the beginning of the National Inclusive Finance (SNKI) program conducted by providing appropriate reports, providing suitable products and financial education. The measure of financial inclusion in this study refers to study from (Dienillah \& Anggraeni, 2016) that uses the ratio of outstanding loans in small and medium enterprises to total outstanding loans in banks.

\section{ANALYSIS AND DISCUSSION Descriptive Statistics}

Table 2 describes descriptive statistics and correlations of the variables in this study. It can be seen that the minimum value of credit risks is Rp. 1,103,307 and the maximum value is Rp. 60,400,000,000 which is the smallest and largest value of bank credit risk. As for the financial inclusion index, the minimum value is 0.1909 and the largest value is 0.3258 which is the index value for 2011 and 2016.

In Panel B Table 2 there is also a correlation matrix between variables. It can be seen that the positive correlation between credit risks and financial inclusion index. This can indicate the positive influence of financial inclusion on credit risks, where there is a possibility that an increase in the financial inclusion index will result in an increase of bank credit risks. However, this still needs to be examined using the best selection model of panel data regression.

\section{Regression Results}

Table 3 summarizes the results of panel data regression with 3 approaches: common effect or pooled OLS regression, fixed effect and random effect. Pooled OLS regression shows the regression results for the common effect. These results indicate that financial inclusion is not significant to credit risk. Furthermore, the two regressions in the fixed effects and random effects models, both show a significant effect between financial inclusion and credit risk, where the direction of effect is positive. This shows that the increase in financial inclusion each year will increase credit risk in banks by $80.9 \%$ (0.809). The test results of the coefficient of determination (R2) show a very small result of $1.23 \%(0.0123)$ where financial inclusion can only affect credit risk of $1.23 \%$. This finding can indi-

Table 2.

Descriptive Statistics and Correlation Matrix

Panel A. Descriptive Statistics

\begin{tabular}{lcllll}
\hline \multicolumn{1}{c}{ Variabel } & \multicolumn{1}{c}{$\mathbf{N}$} & \multicolumn{1}{c}{ Mean } & \multicolumn{1}{c}{ Std. Dev } & \multicolumn{1}{c}{ Min } & \multicolumn{1}{c}{ Max } \\
\hline CRisk & 159 & 63200000000 & 119000000000 & 1103307 & 60400000000 \\
FII & 159 & 0.2641106 & 0.0459157 & 0.1909005 & 0.3258253 \\
\hline
\end{tabular}

Panel B. Correlation Matrix

\begin{tabular}{lll}
\multicolumn{3}{c}{ Crisk } \\
Crisk & 1 & FII \\
FII & $0.1009 \quad 1$ & \\
\hline Notes: Crisk is credit risk which calculated in rupiah. FII is financial inclusion index
\end{tabular}

Table 3.

Panel Data Regression Results

\begin{tabular}{|c|c|c|c|}
\hline Credit Risk & Pooled OLS regression & Fixed effects & Random effects \\
\hline FII & $\begin{array}{l}0.809 \\
(1.42)\end{array}$ & $\begin{array}{l}0.809 * \\
(2.72)\end{array}$ & $\begin{array}{l}0.809 * \\
(2.72)\end{array}$ \\
\hline $\begin{array}{l}\text { Const. } \\
\text { R2 }\end{array}$ & $\begin{array}{l}0.181 \\
0.0123\end{array}$ & $0.180 *$ & $0.181^{*}$ \\
\hline R2-overall & & 0.0123 & 0.0123 \\
\hline $\begin{array}{l}\text { Rho } \\
\text { Prob }>\text { F }\end{array}$ & & $\begin{array}{l}0.954 \\
0.000 \\
\end{array}$ & 0.954 \\
\hline
\end{tabular}


cate that the model's goodness of fit is weak.

However, the value of Rho is quiet high for both fixed effect and random effect model of $95.4 \%$ (0.954) respectively. Rho shows the proportion of variance caused by individual specific terms. The results of this study indicate that the effect of financial inclusion in credit risk can be explained by individual specific terms of financial inclusion of $95.4 \%$ while the remainder is caused by idiosyncratic errors.

To determine the appropriate model in the data panel in this study the Hausman test and LM test were carried out. The results of the Hausman Test and the Lagrage Multiplier Test are summarized in Table 4. From the table it can be seen that the results of the Hausman test are insignificant $(0.9026>0.05)$. So it can be concluded that the fixed effects model is not the right model for the data in this study. Furthermore, the Lagrage Multiplier Test results show significant results $(0.00$ $<0.05$ ), which indicates that the appropriate model in this study is the random effects model.

Therefore, based on the regression results and model suitability testing, it can be concluded that financial inclusion has a significant effect on credit risk for commercial banks in Indonesia (H1 accepted). The direction of the effect of financial inclusion is positive, which shows that increasing financial inclusion will also increase credit risk for commercial banks in Indonesia.

This study found that an increase in financial inclusion would increase the credit risk for commercial banks. This finding is in line with findings from (Musau et al., 2018) which conducted a similar study on commercial banks in Kenya. (Musau et al., 2018) explains that increasing financial in-

Table 4.

Results of Hausman Test and Lagrange Multiplier Test

\begin{tabular}{lcl}
\hline Test & Prob $>$ chi & Prob $>$ chi2 \\
& \multicolumn{2}{c}{$\mathbf{2}$} \\
\hline $\begin{array}{l}\text { Hausman } \\
\text { Breusch-Pagan }\end{array}$ & 0.9026 & \\
Lagrange & & $0.00^{*}$ \\
Multiplier & & \\
\hline Nol & & \\
\hline
\end{tabular}

Notes: * shows significance level at 5\% clusion is directly related to an increase in the number of customers and loans which will increase credit risk to banks.

In Indonesia itself, through the SNKI program, the government encourages increased bank account ownership in communities classified as bottom of the pyramid and also the increase in the use of services provided by financial institutions. This can allow an increase in credit risk due to the inability of customers to pay their debts (default). With the encouragement to increase financial inclusion, commercial banks are expected to reach customers who live in rural or underdeveloped areas, especially for expanding loan funds to communities or MSMEs in the area. To do this, there is a possibility that commercial banks will reduce the requirements or administrative processes for people classified as bottom of the pyramid. This is due to the lack of legal documents to the group. Where this can increase credit risk of the bank.

The findings of this study are also in line with a study from (Ahamed \& Mallick, 2017) which explains that an increase in banking risk can be caused by a lack of ownership of legal identity documents, collateral and credit collectability held by these community groups. Furthermore, an increase in credit risk in banks can affect the stability of the bank. Therefore, it is expected that commercial banks and the government can overcome the effect of increasing financial inclusion so it will not affect the stability of the bank.

\section{CONCLUSION}

This study examines the effect of financial inclusion on credit risk in commercial banks in Indonesia. A total of 34 banks were sampled in this study. The results of data processing concluded that there was an increase in the financial inclusion index in Indonesia from 2011-2016 which showed that more people in Indonesia were using the services of financial institutions. The results of this study also indicate that there is an effect of financial inclusion on bank credit risk where an increase in the financial inclusion index will increase credit risk for commercial banks so that antici- 
patory actions need to be carried out by the banks.

\section{LIMITATIONS AND SUGGESTIONS}

The results of data processing indicate that financial inclusion has an effect on credit risk in commercial banks in Indonesia, but this result also shows that the explanatory power of financial inclusion is still very small, so there are still other factors that can affect credit risk. Therefore, for further study, it is expected to add other variables into the model besides financial inclusion, such as bank competitiveness.

\section{REFERENCES}

Adu, L.A., \& Adjare, D.T. (2010). Determinants of credit risk of commercial banks in Ghana. http:// dx.doi.org/10.213ssrn.2679100. 1-7.

Ahamed, M.M. (2016). Essays on bank profitability, stability, and efficiency: The impact of financial inclusion and bank competition. London.

Ahamed, M.M., \& Mallick, S.K. (2017). Is financial inclusion good for bank stability? International evidence. Journal of Economic Behavior and Organization, Vol 157, 403-427 http:// doi.org/10.1016/j.jebo.2017.07.027.

Bank Indonesia. (2017). Keuangan inklusif. Diakses dari http://www.bi.go.id/

Dienillah, A.A., \& Anggraeni, L. (2016). Dampak inklusi keuangan terhadap stabilitas sistem keuangan di asia. Buletin Ekonomi Moneter dan Perbankan, 18, 409-430.

Dittus, P., \& Klein, M.U. (2011). On harnessing the potential of financial inclusion. SSRN Electronic Journal, (347). http://doi.org/10.2139/ssrn.1859412

Garr, D.K. (2013). Determinants of credit risk in the banking industry of Gha- na. Developing Country Studies, 3(11), 64-78.

Han, R., \& Melecky, M. (2015). Financial inclusion and financial stability: Can broader use of deposits boost resilience of bank funding?. Presented on 11th Annual Conference on Economic Growth and Development, India.

Investopedia. (2018). Credit risks. Diakses dari https://www.investopedia.com/

Manji, A. (2010). Legislation and reports, 73 (June), 985-1004.

Musau, S., Muathe, S., \& Mwangi, L. (2018). Financial inclusion, bank competitiveness and credit risk of commercial banks in Kenya, 9(1), 203-218. http:// doi.org/10.5430/ijfr.v9n1p203

Parlina, I. (2016, November 18). Indonesia promotes financial inclusion with new strategy. The Jakarta Post. Dia k s e s d a r i h t t p : / / www.thejakartapost.com/

Sanjaya, I.M., \& Nursechafia. (2015). Inklusi keuangan dan pertumbuhan inklusif: Analisis antar provinsi di Indonesia. Buletin Ekonomi Moneter Dan Perbankan, 18, 281-306.

Sarma, M., \& Pais, J. (2011). Financial inclusion and development: A cross country analysis. In Annual Conference of the Human Development and Capability Association, New Delhi, (10-13), 130. http://doi.org/10.1002/jid

Thiagarajan, S. (2016). Determinants of credit risk in the commercial banking sector of Belize (February).

Unnikrishnan, R., \& Jagannathan, L. (2015). Unearthing global financial inclusion levels and analysis of financial inclusion as a mediating factor in global human development. Serbian Journal of Management, 10(1), 19-32. http:// doi.org/10.5937/sjm10-5363

World Bank. (2017). Financial inclusion. Dia k s e $\mathrm{d}$ a r i h t p : / / www.worldbank.org/ 